\title{
Pengaruh Pengetahuan, Pendapatan, dan Kepercayaan, Terhadap Minat Muzakki dalam Membayar Zakat di Baitul Mal Kota Lhokseumawe
}

\author{
Mukhlish Muhammad Nur ${ }^{* a}$, Zulfahmi ${ }^{{ }^{* b}}$ \\ *Fakultas Ekonomi dan Bisnis Universitas Malikussaleh \\ a Corresponding author: \\ b zulfahmiekp@gmail.com
}

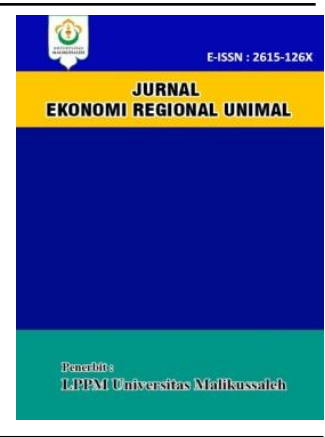

A R T I CLE IN F O RMATION

A B S T R A C T

Keywords :

Knowledge, Income, Trust, and Motivation
This study aims to examine the influence of knowledge, income, and trust of muzzaki on their motivation to pay zakat at Baitul Mal, Lhokseumawe. This study employs quantitative method with 75 traders at Pasar Los, Lhokseumawe, as the samples. The result shows that all independent variables which are identified as Knowledge (X1), income (X2), and trust (X3) simultaneously influence the dependent variable which is identified as muzakki's motivation in paying zakat at BaitulMal, Lhokseumawe (Y). The result suggests that knowledge (X1) and trust (X3) partially influence the muzakki's motivation in paying zakat, while income (X2) does not influence the motivation.

\section{PENDAHULUAN}

Zakat adalah salah satu rukun Islam yang lima, dan zakat hukumnya wajib berdasarkan AlQur'an, As-sunnah, dan Ijma' Ulama yang harus dijalankan oleh umat Islam (Ayyub, 2007). Zakat merupakan ibadah social yang memiliki peran sangat penting, strategis baik dilihat dari segi Agama maupun dari segi pembangunan, kesejahtraan umat (Hafidhuddin, 2007).

Zakat biasa menjadi salah satu instrumen yang dapat digunakan untuk pemerataan pendapatan. Seandainya saja zakat dikelola dengan baik, maka zakat dapat membangun pertumbuhan ekonomi dan juga pemerataan pendapatan, economic with equity (Hafidhuddin, 2007). Di sisi lain zakat juga bisa mengatasi aspek-aspek penting dalam kehidupan. terutama jika menguasai sistem pengelolaan-pengelolaannya dan dengan mengerti bahwa Allah SWT akan menutupi beberapa celah persoalan dalam masyarakat Islam (Ayyub, 2007).

Hikmah dari zakat tidak hanya sebagai perwujudan keimanan dan ketakwaan kepada Allah, tetapi lebih dari itu semua, dengan pengelolaan yang baik, dana zakat dapat menjadi sumber yang bisa dimanfaatkan dan dialokasikan untuk meningkatkan kesejahteraan masyarakat
Islam, dan untuk menciptakan pemerataan pendapatan.

Di Indonesia terdapat dua lembaga pengelolaan zakat yang dipercayai untuk mengoptimalkan pengumpulan dana zakat, lembaga yang dikelola oleh suasta, dan lembaga yang dikelola oleh Pemerintah. Lembaga pemerintah yang berwenang untuk melakukan pengelolaan dan pendistribusian zakat yaitu Badan Amil Zakat dari tingkat Nasional (BAZNAS), Sedangkan lembaga yang dikelola oleh suasta adalah Lembaga Amil Zakat (LAZ) yang telah mendapatkan legalitas dari Pemerintah dalam melakukan pengelolaan dana zakat.

Baitul Mal Kota Lhokseumawe merupakan salah satu Lembaga Amil Zakat yang ada di Kota Lhokseumawe yang memiliki kewajiban sebagai pengganti BAZNAS, adapun peran dan kewajiban tersebut sebagaimana telah diatur di dalam Pasal 12 ayat (1) Qanun Aceh Nomor 10 Tahun 2007 Tentang Baitul Mal. Badan Amil Zakat merupakan lembaga yang dibentuk oleh pemerintah, tujuannya adalah mengumpulkan, mendistribusikan, dan mendayagunakan dana zakat, sehingga dena zakat dapat dikelola dengan baik. Dikarenakan Apabila zakat dikelola dengan 
baik oleh lembaga, maka zakat dapat berperan sebagai instrumen ekonomi yang memiliki kekuatan untuk mengentaskan kemiskinan, pembukaan lapangan kerja, peningkatan pendapatan, dan mendorong tumbuhnya perekonomian masyarakat (Antonio, 2001). Hal tersebut dapat diwujudkan dengan meningkatkan jumlah penerimaan zakat di lembaga dengan terus melakukan upaya penggalian dana zakat (Hafidhuddin, 2007).

Jika melihat fakta bahwa Indonesia merupakan Negara yang memiliki potensi zakat yang sangat besar. Menurut penelitian BAZNAS (Badan Amil Zakat Nasional), potensi zakat Nasional pada tahun 2015 mencapai Rp 286 triliun. Angka ini diperoleh dari hasil ekstrapolasi yang mempertimbangkan pertumbuhan PDB pada tahun-tahun sebelumnya (BAZNAS, 2016). Namum pada kenyataannya hanya terkumpul sedikit jika dibandingkan dengan potensi zakat yang ada, serapan zakat di Indonesia masih rendah. Pada tahun 2016, tercatat zakat masuk Rp 5 triliun. Jumlah tersebut masih sangat jauh bila dibandingkan dengan potensi zakat di Indonesia sebenar nya.

Potensi zakat dapat dihitung dengan menggunakan opini zakat Indonesia (2\%) dan ratarata estimasi zakat dari delapan Negara sebesar 4,3\% „(Hayati \& Caniago, 2011). Tabel berikut menunjukkan potensi zakat di Kota Lhokseumawe.

\section{Tabel 1}

\section{Potensi Zakat di Kota Lhokseumawe Tahun 2012-2015 (Rupiah)}

\begin{tabular}{|ccc|}
\hline \multirow{2}{*}{ Tahun } & $\begin{array}{c}\text { PDRB Kota } \\
\text { Lhokseumawe } \\
\text { (Rupiah) }\end{array}$ & POTENSI ZAKAT \\
\cline { 3 - 3 } 2012 & 9.321 .240 .700 .000 & 186.424 .814 .000 \\
2013 & 9.321 .240 .700 .000 & 186.424 .814 .000 \\
2014 & 9.578 .669 .300 .000 & 191.573 .386 .000 \\
2015 & 9.321 .037 .700 .000 & 186.420 .754 .000 \\
\hline & Total & 750.843 .768 .000 \\
\hline & Rata-Rata & 187.710 .942 .000 \\
\hline
\end{tabular}

Sumber : BPS Kota Lhokseumawe (diolah)

Berdasarkan Tabel 1 dapat dilihat bahwa potensi zakat di Lokseumawe dari tahun 2012-
2015 dengan rata-rata sebesar Rp 187.710.9942.000 (Tabel 1.1) per tahun. Dengan potensi zakat yang begitu besar setiap tahun nya, seharusnya zakat sanagat memungkinkan terciptanya pertumbuhan ekonomi dan pemerataan pendapatan kepada seluruh lapisan masyarakat supaya harta tidak hanya menumpuk di kalangan tertentu, sehingga masalah kemiskinan pun dapat teratasi.

Namun berdasarkan data perhitungan realisasi zakat di Kota Lhokseumawe menunjukan bahwa potensi yang begitu besar belum dapat di realisasikan sebagaimana mestinya.

\section{Tabel 2}

Pencapaian Pengumpulan Zakat di Kota Lhokseumawe Tahun 2012-2015 (Rupiah)

\begin{tabular}{|cc|}
\hline Tahun & $\begin{array}{c}\text { Realisasi Zakat Lhokseumawe } \\
\text { (Rupiah) }\end{array}$ \\
\hline 2012 & 1.991 .790 .547 \\
2013 & 1.403 .134 .603 \\
2014 & 4.967 .445 .818 \\
2015 & 6.567 .773 .930 \\
\hline Jumlah & 13.138 .144 .898 \\
Rata-Rata & 3.732 .536 .224 \\
\hline
\end{tabular}

Sumber : BPS Provinsi Aceh

Berdasarkan Tabel 2 diketahui bahwa realisasi zakat di Kota Lhokseumawe dalam kurun waktu 2012-2015 sebesar Rp 13.138.144.898 (Tabel 1.2), dengan rata-rata $\mathrm{Rp}$ 3.732.536.224 (Tabel 1.2), setiap tahunnya, jika dibandingkan dengan potensi zakat yang ada di Kota Lhokseumawe maka pencapaian ini masih sangat sangat keci, dapat dilihat pada Tabel 1.1 rata-rata potensi zakat setiap tahunnya di Kota Lhokseumawe adalah Rp 187.710.950.000 (Tabel 1.1), Namun dana zakat yang dapat terserap di Baitul Mal Kota Lhokseumawe hanya sebesar Rp 3.732.536.224 (Tabel 1.2) atau sekitar 2\% dari potensi zakat kota Lhokseumawe.

Kesenjangan yang sangat besar antara dana zakat yang terkumpul dan potensi zakat yang ada hal tersebut menandakan bahwa Baitul Mal yang ada di Kota Lhokseumawe kurang dimanfaatkan oleh penduduk Muzakki Kota Lhokseumawe. Untuk itu penulis tertarik untuk meneliti apakah 
yang menjadi penyebab kurangnya minat muzakki untuk membayar zakat di Baitul Mal.

Kurangnya minat muzakki untuk membayar zakat di Baitul Mal dipengaruhi oleh beberapa hal. Yang pertama, ketidaktahuan kewajiban membayar zakat. Menurut Hafidhuddin salah satu penyebab belum terkumpul zakat secara keseluruhan di lembaga-lembaa pengumpul zakat, kerena pengetahuan masyarakat terhadap harta yang wajib dikeluarkan zakatnya masih terbatas pada sumber-sumber konfensional yang secara jelas dinyatakan dalm Al-Quran dan Hdits dengan pernyataan tertentu (Hafidhuddin, 2007).

Kedua, Pendapatan juga diyakini merupakan faktor yang mempengaruhi minat masyarakat membayar zakat. Islam menyatakan bahwa, seseorang diwajibkan membayar zakat apabila pendapatan yang dimiliki telah mencapai nisab dan haulnya, dan sebaliknya apabila seseorang yang memiliki pendapatan belum mencapai nisab dan haulnya, maka orang tersebut tidak wajib mengeluarkan zakatnya.

Ketiga, ketidakpercayaan terhadap Lembaga Pengelola Zakat. Salah satu faktor yang mempengaruhi keengganan masyarakat membayar zakat pada BAZ/LAZ adalah kurangnya kepercayaan dari masyarakat terhadap BAZIS/LAZ dalam menyalurkan zakat kepada mustahiq (Daulay \& Lubis, 2006). sehingga sebagian masyarakat mengeluarkan zakatnya tidak melalui Amil zakat tetapi langsung kepada Mustahiq.

Jika pengetahuan, pendapatan dan kepercayaan muzakki terhadap lembaga pengelola zakat semakin meningkat maka Minat Muzakki membayar zakat pada lembaga pengelola zakat semakin meningkat, namun sebaliknya jika tingkat Pengetahuan, Pendapatan dan kepercayaan muzakki menurun maka minat muzakki untuk membayar zakat di Baitul Mal juga akan menurun.

Berdasarkan uraian diatas, Oleh sebab itulah peneliti tertarik untuk melakukan penelitian tentang hal apa saja yang mempengaruhi minat muzakki dalam membayar zakat di Lembaga Pengelolaan Zakat. Oleh karena itu peneliti tertarik mengambil judul "Pengaruh Pengatahuan, Pendapatan, dan Kepercayaan Muzakki
Terhadap Minat Muzakki Dalam Membayar Zakat di BaitulMal Kota Lhokseumawe".

Penelitian ini bertujuan untuk mengetahui pengaruh pengetahuan, pendapatan, dan kepercayaan terhadap minat muzakki untuk membayar zakat di Baitul Mal Kota Lhokseumawe serta perhitungan-perhitungan statistik menguji hipotesis.

\section{TINJAUAN TEORITIS \\ Pengetahuan Zakat}

Dalam Islam pengetahuan diistilahkan dengan Al-ilmu, yang mempunyai dua pengertian, pertama pengetahuan yang berasal dari wahyu Allah untuk mengenal-Nya dan kedua, pengetahuan yang diperoleh oleh manusia itu sendiri naik melalui pengamalan (empiris), rasional dan intuisi. Pembelajaran dapat mencakupi perubahan-perubahan prilaku yang timbul berdasarkan pengalaman, Sebahagian besar dari perilaku seseorang ditentukan melalui proses pembelajaran, dimana pembelajaran akan menjadi sebuah pengetahuan yang akan berpengaruh terhadap perilaku seseorang, termasuk perilaku para muzakki (Rangkuti, 2009).

Salah satu sebab zakat belum terkumpul secara optimal di lembaga amil zakat, dikarenakan pengetahuan terhadap harta yang wajib dikeluarkan zakat nya masih terbatas pada sumber-sumber konfensional yang secara jelas dinyatakan dalm Al-Quran dan hdits dengan pernyataan tertentu (Ayyub, 2007).

\section{Definisi Zakat}

Zakat merupakan kewajiban yang wajib dikeluarkan dari bagian hartanya atas perintah Allah untuk disalurkan lagi kepada pihak-pihak yang berhak menerimanya (Sabiq, 1946). Jika zakat ditinjau dari segi istilah, zakat merupakan kewajiban yang telah diwajibkan oleh Allah bagi setiap kaum Muslim yang memiliki harta lebih dengan memenuhi beberapa persyaratan yang telah ditetapkan oleh Allah, untuk diserahkan dan disalurkan kapada pihak-pihak yang berhak menerimanya (Hafidhuddin, 2007).

Secara bahasa, zakat berarti "bersih", "berkembang", dan "berkah". Dengan kata lain kata zakat bisa diartikan "membersihkan", "bertambah", "berkembang”, dan "diberkahi”. 
Apabila kita lihat dari sisi orang yang mengeluarkannya,Allah akan mengampuni dosadosanya, dan membuat tenang jiwanya, dikarenakan berkat dari doa-doa orang-oarang penerima zakat.

\section{Hukum Zakat}

Dalam ajaran Islam disebutkan bahwa zakat merupakan rukun Islam yang ke tiga dan disebutkan setelah Shalat, sehingga dalam AlQuran 82 kali perintah zakat selalu disandingkan dengan perinta shalat. Hal Ini menunjukkan hukum dasar zakat yang sangat kuat (Hasan, 2008).

Zakat adalah bagian dari kewajiban Islam yang telah disepakati dan diakui oleh umat Islam dan telah sangat masyhur sehingga menjadi bagian dari fondasi-fondasi Islam. Jika ada salah seorang mengingkari kewajiban zakat, ia telah keluar dari Agama Islam dan berhak dibunuh (jika masih tetap mengingkari nya). Adapun orang yang enggan membayar zakat, namun masih tetap meyakini kewajibannya, ia telah berdosa karena keengganannya tersebut tampa mengeluarkannya dari Agama Islam. Penguasa berhak mengambil zakat darinya secara paksa dan memberikan hukuman takzir kepadanya (Sabiq, 1946).

Dengan demikian, zakat hukumnya wajib.

Dari penjelasan diatas zakat tidak hanya mempunyai dimensi vertikal namun zakat juga memiliki dimensi horizontal. Dikerenakan tujuan zakat selain sebagai perujudan keimanan kepada Allah SWT. Zakat juga memiliki beberapa fungsi dan tujuan, yaitu fungsi sosial ekonomi sebagai perwujudan solidaritas sosial, untuk meningkatkan rasa keadilan dan kemanusiaan, mempererat persaudaraan dalam Islam, pemersatu Umat, sebagai rasa peduli orang kaya terhadap orang miskin, mewujudkan kondisi masyarakat yang sejahtera dan aman, rukun, damai, dan harmonis sehingga pada akhirnya akan menciptakan situasi yang aman sendosa.

\section{Hikmah dan Manfaat Zakat}

Di dalam zakat terkandung manfaat dan hikmah yang besar, dan mulia, baik hikmah untuk muzakki ataupun hikmah untuk orang yang menerima (mustahik), dan hikmah untuk harta yang dikeluarkan zakatnya, maupun bagi lapisan masyarakat keseluruhan. Hikmah dan manfaat tersebut antara lain (Hafidhuddin, 2007) :

1. Sebagai perujudan keimanan kepada Allh SWT, mensyukuri nikmat yang telah diberikan oleh-Nya, dapat menumbuhkan rasa kemanusiaan,sifat kikir akan hilang, materialistis dan rakus,hidup tenang, sekaligus mensucikan dan menumbuhkan harta yang dimiliki.

2. Zakat merupakan hak mustahik, maka zakat yang diberikan untuk mustahik, berfungsi utuk membantu, menoling mereka para fakir miskin untuk menciptakan kondisi kehidupan yang lebih sejahtera,sehingga dengan demikian mereka dapat memenuhi kebutuhan hidupnya dengan layak, dapat beribadah kepada Allah SWT, terhindar dari banyak kekufuran, sekaligus menghilangkan sifat iri, dengki dan hasad yang mana akan timbul dari kalangan mereka, ketika mereka menyaksikan harta orang kaya yang cukup banyak.

3. Sebagai pilar amal jama'i antara orang-orang berkecukupan yang memiliki harta yang lebih dan orang-orang yang berjihad di jalan Allah.

4. Sebagai sumber suntikan dana untuk membangun sarana dan presarana yang harus dimiliki oleh umat Islam, seperti sarana ibadah, kesehatan, pendidikan, sosial, maupun ekonomi, sekaligus sarana pengembangan kualitas sumberdaya manusia Muslim.

5. Untuk memasyarakatkan etika bisnis yang benar, sebab zakat itu bukanlah membersihkan harta yang kotor, akan tetapi mengeluarkan bagian dari hak orang lain dari harta kita yang kita usahakan dengan baik dan benar.

6. Dari sisi pembangunan kesejahtraan ummat, zakat merupakan salah satu instrumen pemerataan pendapatan. Dorongan ajaran Islam yang begitu kuat kepada orang-orang yang beriman untuk berzakat, berinfak, dan bersedekah menunjukkan bahwa ajaran Islam mendorong umatnya untuk mampu bekerja dan berusaha sehingga memiliki harta kekayaan yang di samping dapat memenuhi kebutuhan hidup diri dan keluarganya, juga berlomba - lomba menjadi muzakki. 
Pendapatan Pendapatan ialah tambahan harta yang diperoleh dari sumber yang diketahui dan bersifat tetap.

\section{Pendapatan}

Pendapatan adalah keuntangan yang bersifat materi ataupun non materi yang diperoleh melalui usaha tertentu. Islam tidak hanya mewajibkan zakat atas kekayaan namun juga mewajibkan zakat atas pendapatan, seperti zakat atas pendapatan hasil pertanian, hasil barang dagangan, dan hasil lain yang diperoleh dari berbagai pekerjaan dan usaha.

Syarat harta yang harus dipenuhi dalam kewajiban zakat sebagai berikut (Inoed 2005):

1. Kepemilikan harta yang pasti dan kepemilikan penuh

2. Berkembang.

3. Milik penuh.

4. Melebihi kebutuah pokok.

5. Bersih dari hutang.

6. Mencapai nishab.

7. Mencapai haul.

8. Sejumlah kadar tertentu.

\section{Kepercayaan}

Kepercayaan (thrust) adalah ekspektasi atau pengharapan positif bahwa orang lain tidak akan melalui katakata, tindakan, dan kebijakan bertindak secara oportunistik (Gito, 2002). Konsep kepercayaan secara umum dapat dibedakan kedalam dua jenis, yaitu political trust (kepercayaan politik) dan social trust (kepercayaan sosial). Dalam persepektif politik, kepercayaan terjadi ketika menilai lembaga pemerintah dan para pemimpinnya dapat memenuhi janji, efisien, adil, dan jujur (Dwiyanto, 2011). Untuk membangun sebuah kepercayaan diperlukan tujuh core values, yaitu sebagai berikut (Wibowo, 2006) :

\section{Keterbukaan}

Kerahasiaan dan kurangnya transparansi antara ke duabelah pihak dalam menjalankan kerja sama akan mengganggu trust building. Oleh karena itu diperlukan keterbukaan antara kedua belah pihak agar keduanya dapat saling percaya antara satu sama lain.

\section{Kompeten}

Kompeten merupakan salah satu hal yang sangat penting yang harus kita miliki, dikarenakan jika seseorang ingin memperoleh kepercayaan dari masyarakat maka perlu adanya kemampuan untuk melaksanakan yang telah dibebankan kepada nya.

3. Kejujuran

Kejujuran Kejujuran merupakan elemen terpenting dalam mendapatkan sebuah kepercayaan, dengan adanya kejujuran maka hal-hal yang bersifat merugikan yang lain dapat terhindar. Jujur bermakna kesesuaian antara informasi yang yang diberikan dengan kenyataan yang ada. Dengan kata lain jujur adalah setiap pernyataan yang kita lontarkan sesuai dengan kenyataan dan kebenaran.

4. Integritas

Integritas adalah kesesuwaian antara perkataan, itikat, pemikiran dan tindakan. Dalam perkataannya berjanji akan melaksanakan tugas-tugasnya secara professional untuk menghasilkan sumberdaya yang optimal.

5. Akuntabilitas

Akuntabilitas adalah dorongan yang dimiliki seseorang untuk mempertanggung jawabkan sesuatu yang telah dikerjakan kepada lingkungannya atau orang lain. Akuntabilitas sekiranya dapat diukur dengan pertanyaan-pertanyaan tentang seberapa besar motivasi menyelesaikan pekerjaan dan seberapa besar usaha (daya pikir) untuk menyelesaikan pekerjaan-pekerjaan tersebut.

6. Sharing

Sharing adalah sebuah pengakuan atau pengungkapan diri terhadap orang lain yang berfungsi untuk berbagi sesuatu untuk meringankan sebuah masalah. Sharing merupakan elemen penting dalam membangun kepercayaan karena mempunyai manfaat nilai psikologis yakni membantu membangun hubungan yang lebih baik antara satu sama lain. Termasuk didalamnya sharing informasi, ketrampilan, pengalaman dan keahlian. 
7. Penghargaan.

Untuk mendorong sebuah kepercayaan maka harus terdapat respek saling menghargai antara satu sama lain.

\section{Minat Membayar Zakat}

Minat adalah suatu perangkat mental yang terdiri dari suatu campuran dari peresaan, harapan, pendirian, prasangka, rasa takut atau kecenderungan-kecenderungan lain yang mengarahkan individu kepada suatu pilihan tertentu(Mappiare, 2000).

Macam-macam minat(Hapsari, 2005) :

1. Minat pembawaan adalah minat yang muncul berdasarkan bakat dan IQ yang dimiliki seseorang.

2. Minat hasil belajar adalah minat yang muncul karena pengaruh dari luar diri kita.

3. Pengaruh lingkungan pergaulan.

4. Kesehatan mental dan fisik seseorang.

\section{Faktor-Faktor yang Mempengaruhi Minat}

Faktor-faktor yang mempengaruhi timbulnya minat Menurut Crow and Crow dalam bukunya Abdul Rahman Saleh berpendapat ada tiga faktor yang mempengaruhi timbulnya minat yaitu (Hapsari, 2005) :

1. Dorongan dari dalam diri individu, misal dorongan makan, rasa ingin tahu dan seks. Muzakki yang telah mengetahui tentang kewajiban terhadap harta yang dimilikinya, dan dengan ada kesedaran dalam individu muzakki, maka muzakki senantiasa memiliki komitmen untuk mengeluarkan zakat setiap tahunnay.

2. Motif sosial, dapat menjadi faktor yang membangkitkan minat untuk melakukan suatu aktivitas tertentu. Dorongan dari luar sangat menentukan seseorang untuk membayar zakat, misalkan dorogan dari keluarga, teman, dan dorongan deri lingkungan sekitarnya.

3. Faktor emosional, minat mempunyai hubungan yang erat dengan emosi. Setiap muzkki yang mengeluarkan zakat pasti akan dilipat gandakan hartanya oleh Allah, dan muzakki mengharabkan balasan dari Allah.

\section{METODE PENELITIAN}

\section{Objek dan Lokasi Penelitian}

Yang dimaksud obyek penelitian, adalah hal yang menjadi sasaran penelitian (M. Moeliono, 1999). Obyek penelitian, adalah pokok persoalan yang hendak diteliti untuk mendapatkan data secara lebih terarah. Adapun Obyek penelitian dalam penelitianini meliputi: (X1) pengetahuan (X2)pendapatan, (X3)kepercayaan, dan (Y) minat muzakki. Sedangkan lokasidalam penelitian ini penulis mengambil lokasi di Pasar Los Kota Lhokseumawe.

\section{Populasi}

Populasi adalah kumpulan dari semua kemungkinan orang-orang, benda-benda, dan ukuran lain yang menjadi objek perhatian atau kumpulan seluruh objek yang menjadi perhatian,(Suharyadi, 2004).Adapun populasi dalam penelitian ini adalah semua pengusaha yang ada di Pasar Los Kota Lhokseumawe yaitu sebanyak 302 orang (Sumber : Kantor Desa Kota)

\section{Sampel}

Menurut Sugiyono (Sugiono, 2010) sampel adalah bagian dari jumlah dan karakteristik yang dimiliki populasi tersebut.Dalam penelitian ini teknik yang digunakan untuk pengambilan sampel adalah teknik non-probilitas, merupakan teknik yang tidak memberikan peluang atau kesempatan sama bagi setiap unsur atau anggota populasi untuk dipilih menjadi sampel. Cara pengambilan sample yang di gunakan dalam penelitian ini adalah metode purposive sampling. Dengan Kriteria sebagai berikut :

1. Muzakki yang berjualan di ruko-ruko pasar los Kota Lhokseumawe.

2. Muzaki yang sudah membayar zakat 2 tahun berturut-turut atau lebih.

Pengambilan sampel diperoleh berdasarkan rumus slovin :

$$
\mathrm{n}=\frac{N}{1+N e^{2}}
$$


Dimana:

$\mathrm{n} \quad=$ Ukuran sampel

$\mathrm{N}=$ Ukuran Populasi

e =Kelonggaran ketidaktelitian karena kesalahan pengambilan sampel

yang dapat ditolerir (10\%). Besarnya populasi diketahui sebesar 302. Jadi besarnya sampel yang digunakan adalah:

$$
\begin{aligned}
& \mathrm{n}=\frac{302}{1+302(10 \%)^{2}} \\
& \mathrm{n}=75.124
\end{aligned}
$$

Untuk memudahkan peneliti dalam pengolahan data maka peneliti membulatkan sampel dari 75.124 menjadi 75 sampel.

\section{HASIL PENELITIAN DAN PEMBAHASAN}

\section{Uji Validitas}

\section{Tabel 3}

Uji Validitas

\begin{tabular}{lrrrr}
\hline No & Indikator & $\begin{array}{c}\text { r } \\
\text { tabel }\end{array}$ & $\begin{array}{c}\mathbf{r} \\
\text { hitung }\end{array}$ & Ket \\
\hline 1 & Pengetahuan (X1) & &
\end{tabular}

1. Saya mengetahui bahwa zakat adalah sejumlah harta tertentu yang diwajibkan oleh ALLAH SWT untuk diberikan kepada orang-orang berhak menerimanya.

2. Saya selalu menyisihkan $2,5 \%$ pendapatan saya untuk diberikan kepada orang yang membutuhkan.

3. Membayar zakat sama pentingnya dengan shalat.

4. Saya dapat menghitung besaran jumlah zakat yang harus saya keluarkan.

\section{$0,194 \quad 0,453 \quad$ Valit}

0,879 Valit

0,866 Valit

$2 \quad$ Pendapatan (X2)

1. Harta yang saya zakati merupakan dari hasil pendapatan saya sendiri dan kepemilikan mutlak punya saya.

2. Salah satu alasan saya membayar zakat, karena saya memiliki pendapatan atau harta kekayaan lebih dan sifatnya berkembang.

3. Saya membayar zakat dikarenakan pendapatan saya mencapai nisab.

0,797 Valit

4. Saya membayar zakat setelah harta saya mencapai haul.

0,691 Valit

\section{Kepercayaan (X3)}

1. Baitul Mal adalah lembaga yang amanah.

0,873 Valit

2. Keberadaan Baitul Mal sebuah lembaga yang memudahkan dalam

0,879 Valit mengeluarkan zakat.

3. Baitul Mal $\mathbf{0 , 1 9 4}$ mempublikasikan pertanggung jawabannya

0,886 Valit kepada media.

4. Baitul Mal menyeleksi calon Mustahiq secara transparant.

0,781 Valit 4. $\quad$ Minat (Y)

1. Saya berminat membayar zakat di Baitul Mal karena Baitul Mal 0,752 Valit lembaga yang amanah

2. Saya berminat membayar zakat di Baitul Mal karena Baitul Mal memberi bantuan kepada fakir miskin

3. Saya berminat membayar zakat di Baitul Mal karena saya mengetahui bahwa Baitul Mal telah

0,860 Valit memberi bantuan kepada pedagang kecil yang ada di Pasar Los

4. Saya sangat termotivasi untuk mengeluarkan zakat melalui Lembaga

\section{0,194} Baitul Mal.

Sumber: Pengolahan Data SPSS Versi 16.00 (2018).

Berdasarkan tabel 3 di atas, maka diperoeh bahwa semua indikator yang digunakan untuk mengukur variabel-variabel yang digunakan dalam penelitian ini memiliki koefisien korelasi yang lebih besar dari $r$ tabel $=0.230$ ( nilai $r$ tabel untuk $\mathrm{n}=75$ ), semua indikator tersebut adalah valid.

\section{Tabel 4}

Uji Reabilitas

\begin{tabular}{lccc}
\hline \multicolumn{1}{c}{ Variabel } & $\begin{array}{c}\text { Cronbach } \\
\text { Alpha }\end{array}$ & $\begin{array}{c}\text { Indikator } \\
\text { Variabel }\end{array}$ & Ket \\
\hline Pengetahuan (X1) & 0,739 & 4 & Reabilitas \\
\hline Pendapatan (X2) & 0,825 & 4 & Reabilitas \\
\hline Kepercayaan (X3) & 0,878 & 4 & Reabilitas \\
\hline Minat (Y) & 0,792 & 4 & Reabilitas \\
\hline
\end{tabular}


Sumber: Pengolahan Data SPSS Versi 16.00 (2018)

Berdasarkan tabel 4 di atas diketahui bahwa variabel $\left(\mathrm{X}_{1}\right)$, pengetahuan $\left(\mathrm{X}_{2}\right)$, pendapatan $\left(\mathrm{X}_{3}\right)$, dan kepercayaan $(\mathrm{Y})$ minat menunjukkan nilai cronbach Alpha $>0.60$ yang berarti semua variabel realiabel. Hal ini menunjukkan bahwa item pertanyaan yang digunakan mampu memperoleh data yang konsisten dalam arti jika pertanyaan tersebut diajukan kembali akan diperoleh jawaban yang relatif sama.

\section{Hasil Pengujian Normalitas Data K-S \\ Tabel 5 \\ Uji Normalitas}

\begin{tabular}{llr}
\hline \multicolumn{2}{c}{ One-Sample Kolmogorov-Smirnov Test } \\
\hline & & $\begin{array}{r}\text { Unstandardi } \\
\text { zed Residual }\end{array}$ \\
\hline $\mathrm{N}$ & 75 \\
Normal Parameters & a & Mean \\
& Std. Deviation & .0000000 \\
Most Extreme & Absolute & .99889689 \\
Differences & Positive & .070 \\
& Negative & -.084 \\
Kolmogorov-Smirnov Z & .726 \\
\hline Asymp. Sig. (2-tailed) & .667 \\
\hline
\end{tabular}

Sumber: Pengolahan Data SPSS Versi 16.00 (2018)

Berdasarkan tabel 5 diketahui bahwa nilai Asymp.Sig. (2- tailed) sebesar $0.667>0.05$ maka H0 diterima. Sehingga dapat disimpulkan bahwa data yang kita uji berdistribusi normal.

Tabel 6

\section{Uji Multikolinieritas}

\begin{tabular}{ccc}
\hline & \multicolumn{2}{c}{ Collinearity Statistics } \\
\cline { 2 - 3 } Model & Tolerance & VIF \\
\hline (Constant) & & \\
PENGETAHUAN & .768 & 1.302 \\
PENDAPATAN & .834 & 1.199 \\
KEPERCAYAAN & .667 & 1.499 \\
\hline
\end{tabular}

Sumber: Pengolahan Data SPSS Versi 16.00 (2018)

Dari tabel 6 diatas dapat dilihat bahwa semua variabel memiliki nilai VIF $<10$ dan nilai tolerance > dari 0,1. Hal ini menunjukan bahwa tidak terjadi multikolonieritas dan uji ini baik digunakan dalam model penelitian ini.

\section{Tabel 7}

Hasil Uji Heteroskedastisitas - Uji Glejser Coefficients $^{\mathrm{a}}$

\begin{tabular}{lrrrrrr}
\hline & \multicolumn{5}{c}{$\begin{array}{c}\text { Standar- } \\
\text { dized }\end{array}$} \\
& \multicolumn{7}{c}{$\begin{array}{c}\text { Unstandardized Coeffici } \\
\text { Coefficients }\end{array}$} & ents & & \\
\cline { 2 - 5 } Model & B & Error & Beta & T & Sig. \\
\hline 1(Constant) & - & 1.645 & & -1.282 & .204 \\
PENGETAHUAN & .149 & .093 & .209 & 1.607 & .112 \\
PENDAPATAN & .137 & .074 & .231 & 1.856 & .068 \\
KEPERCAYAAN & -.090 & .075 & -.168 & -1.202 & .233 \\
\hline a. Dependent Variable: & & & & & \\
RES2 & & & & & \\
\hline
\end{tabular}

Sumber: Pengolahan Data SPSS Versi 16.00 (2018)

Berdasarkan hasil uji heteroskedastisitas melalui uji Glejser pada tabel 4.9dapat dlihat bahwa tidak ada satupun variabel yang signifikansinya dibawah 0,05 . Dan dapat dikatakan bahwa masing- masing variabel tidak mengalami masalah heterokedastisitas. Dan variabel-variabel independen dapat dinyatakan tidak mengalami heteroskedastisitas.

Tabel 8

Hasil Analisis Regresi Linear Berganda

\begin{tabular}{llccc}
\hline \multirow{2}{*}{ Model } & \multicolumn{2}{c}{$\begin{array}{c}\text { Unstandardized } \\
\text { Coefficients }\end{array}$} & $\begin{array}{c}\text { Standardized } \\
\text { Coefficients }\end{array}$ \\
\cline { 3 - 5 } & & B & $\begin{array}{c}\text { Std. } \\
\text { Error }\end{array}$ & Beta \\
\hline 1 & (Constant) & 0.692 & 2.625 & \\
& pengetahuan & .313 & .148 & .231 \\
pendapatan & .028 & .118 & .025 \\
kepercayaan & .442 & .120 & .433 \\
\hline
\end{tabular}

Sumber: Pengolahan Data SPSS Versi 16.00 (2018)

Berdasarkan Tabel 8 tersebut diperoleh persamaan regresi linear berganda sebagai berikut: $Y=0.692+0.313 X_{1}+0.028 X_{2}+0.442 X_{3}$

Dari persamaan regresi tersebut dapat dilihat bahwa besarnya nilai konstanta adalah 0.693 hal ini berarti jika pengetahuan (X1), pendapatan (X2) dan kepercayaan (X3) konstan 
(bernilai 0), maka minat nilainya sebesar. 0.692 Koefisien regresi variabel pengetahuan(X1) sebesar 0.313 yang berarti bahwa apabila pengetahuan (X1) ditingkatkan 1 satuan skala likert maka minat membayar zakat (Y) akan meningkat sebesar 0.313. Koefisien regresi variabel pendapatan (X2) sebesar 0.028 yang berarti bahwa apabila pendapatan (X2) ditingkatkan 1 satuan skala likert maka minat membayar zakat (Y) akan meningkat sebesar 0.028. Koefisien regresi variabel kepercayaan (X3) sebesar 0.442yang berarti bahwa apabila kepercayaan (X3) ditingkatkan 1 satuan skala likert maka minat membayar zakat (Y) akan menurun sebesar 0.442 .

\section{Uji Simultan (Uji F)}

Perhitungan yang diperoleh pada Tabel 4.13 dapat diketahui bahwa nilai $\mathrm{F}_{\text {hitung }}$ lebih besar dari nilai $F_{\text {tabel }}(12.688>2.733)$, dan nilai signifikan (sig) $=0,000$ yang lebih kecil dari nilai $\alpha$ $=0,05$. Hasil perhitungan regresi menunjukkan bahwa hipotesis alternatif $\mathrm{Ha}$ diterima. Hal ini berarti bahwa variabel pengetahuan (X1), pendapatan (X2) dan kepercayaan (X3) secara simultan berpengaruh signifikan terhadap minat muzakki mambayar zakat di Baitul Mal Kota Lhokseumawe.

\section{Uji Parsial (Uji t)}

Hasil perhitungan regresi menunjukkan bahwa hipotesis alternatif $\mathrm{Ha}$ diterima, hal ini berarti bahwa pengetahuan berpengaruh terhadap minat muzakki untuk membayar zakat. Hal tersebut ditunjukkan dengan nilai t hitung sebesar 2.117dan lebih besar dari nilai t tabel (df=n-k) pada $n=75$ sebesar 1.666 . Pada level $5 \%$ dan nilai signifikan sebesar 0,038 Lebih kecil dari alpha $(\alpha)$ 0,05 .

\section{Variabel pendapatan}

Hasil perhitungan regresi menunjukkan bahwa hipotesis alternatif Haditolak dan menerima Ho, hal ini berarti bahwa pendapatan tidak berpengaruhterhadap minat muzakki. Hal tersebut ditunjukkan dengan nilai t hitung sebesar 0.234dan lebih kecildari nilai $\mathrm{t}$ tabel $(\mathrm{df}=\mathrm{n}-\mathrm{k}-1)$ pada $\mathrm{n}=75$ sebesar 0.166 Pada level 5\% dan nilai signifikan sebesar 0,816 Lebih besar dari alpha $(\alpha) 0,05$. Yang berarti pendapatan tidak berpengaruh terhadap minat.

\section{Variabel kepercayaan}

Hasil perhitungan regresi menunjukkan bahwa hipotesis alternatif $\mathrm{Ha}$ diterima, hal ini berarti bahwa kepercayaan berpengaruh secara signifikanterhadap minat muzakki. Hal tersebut ditunjukkan dengan nilai t hitung sebesar 3.695dan lebih besar dari nilai $\mathrm{t}$ tabel $(\mathrm{df}=\mathrm{n}-\mathrm{k}-1)$ pada $\mathrm{n}=75$ sebesar 1.66 Pada level 5\% dan nilai signifikan sebesar 0,000 Lebih kecil dari alpha $(\alpha)$ 0,05.

\section{KESIMPULAN DAN SARAN Kesimpulan}

Berdasarkan hasil penelitian mengenai pengaruh pengetahuan, pendapatan, dan kepercayaan terhadap minat muzakki untuk membayar zakat di Baitul Mal Kota Lhokseumawe yang telah dibahas serta perhitungan-perhitungan statistik menguji hipotesis yang telah dilakukan dengan analisis regresi linier bergada dan pembahasan analisis data yang dilakukan, maka penulis menarik kesimpulan sebagai berikut.

1. Pengetahuan (X1) Berpengaruh secara parsial dan signifikan terhadap minatmuzakki (Y) membayar zakat di Baitul Mal Kota Lhokseumawe, Hal tersebut ditunjukkan dengan nilai $\mathrm{t}$ hitung sebesar 2.117 lebih besar dari nilai t tabel 1.666. Pada level 5\% dan nilai signifikan sebesar 0,038 Lebih kecil dari alpha $(\alpha)$ 0,05 .

2. Pendapatan (X2) tidak berpengaruh terhadap minat muzakki (Y) membayar zakat di Baitul Mal Kota Lhokseumawe. Hal tersebut ditunjukkan dengan nilai $\mathrm{t}$ hitung sebesar 0.234 lebih kecil dari nilai $\mathrm{t}$ tabel sebesar 1.666 Pada level 5\% dan nilai signifikan sebesar 0,816 Lebih besar dari alpha $(\alpha) 0,05$. Yang berarti pendapatan tidak berpengaruh terhadap minat.

3. Kepercayaan (X3) Berpengaruh secara parsial dan signifikan terhadap minat muzakki (Y) membayar zakat di Baitul Mal Kota Lhokseumawe. Hal tersebut 
ditunjukkan dengan nilai t hitung sebesar 3.695 lebih besar dari nilai t tabel sebesar 1.666 Pada level 5\% dan nilai signifikan sebesar 0,000 Lebih kecil dari alpha $(\alpha)$ 0,05 .

4. Variabel Pengetahuan (X1), Pendapatan (X2), Kepercayaan (X3), berpengaruh secara simultan terhadap minat (Y). Hal tersebut ditunjukkan dari nilai $F_{\text {hitung }}$ lebih besar dari nilai $F_{\text {tabel }}(12.688>2.733)$, dan nilai signifikan (sig) $=0,000$ yang lebih kecil dari nilai $\alpha=0,05$.

5. Berdasarkan hasil penelitian, maka dapat disimpulkan bahwa variabel yang paling dominan dalam penelitian ini adalah kepercayaan muzakki.

\section{Saran}

Berdasarkan kesimpulan penelitian yang dikemukakan di atas, maka peneliti memberikan beberapa saran sebagai berikut:

1. Saran bagi Pihak lembaga Baitul Mal di Kota Lhokseumawe agar lembaga Baitul Mal dapat lebih meningkatkan lagi kinerja lembaga baik dalam hal manajemen lembaga pengelola zakat, penyaluran, penghimpunan, dan pendapayagunaan dana secara transaparansi, Sehingga dengan peningkatan kinerja tersebut dapat meningkatkan kepercayaan para muzakki terhadap Baitul Mal Kota Lhokseumawe.

2. Pihak Lembaga Baitul Mal Kota Lhokseumawe sekiranya perlu membuat penyeluhan bagi para pedagang Pasar Los untuk menumbuhkan minat berzakat mereka di Baitul Mal Kota Lhokseumawe, dengan harapan ketika wawasan mereka bertambah sehingga minat mereka untuk membayar zakat di Baitul Mal pun ikut bertambah.

3. Untuk memperoleh hasil studi yang lebih baik, maka perlu dilakukan uji lagi tentang faktor-faktor yang dapat mempengaruhi minat muzakki untuk membayar zakat di Baitul Mal Kota Lhokseumawe dengan menambahkan variabel bebas yang lebih banyak.
4. Untuk akademik yang sejalan dengan penelitian ini diharapkan dapat dilanjutkan oleh peneliti lain dengan objek dan sudut pandang yang berbeda sehingga dapat mengembangkan penelitian dalam Ekonomi Islam.

\section{DAFTAR PUSTAKA}

Antonio, S. M. (2001). Bank syariah. Jakarta: Gema insani.

Ayyub, H. (2007). Fiqih Ibadah. Depok: PT Fathan Prima Media.

BAZNAS. (2016). Outlook Zakat Indonesia 2017. Jakarta Pusat: Pusat Kajian Strategis BAZNAS.

Daulay, A. H., \& Lubis, I. (2006). Analisis FaktorFaktor Penyebab Keengganan Masyarakat Membayar Zakat Melalui Instansi Bazis/Laz di Kota Medan ( Studi Kasus: Masyarakat Kecamatan Medan Tembung ). Jurnal Ekonomi Dan Keuangan, Vol.3 No.(38), 241251 .

Dwiyanto, A. (2011). Mengembalikan Kepercayaan Publik Melalui Reformasi Birokrasi. Jakarta: PT Gramedia pustaka utama.

Gito, S. (2002). Perilaku Organisasi. Jakarta: Salamba Empat.

Hafidhuddin, D. (2007). Zakat Dalam Perekonomian Modern. Gema Insani Press. jakarta: Gema insani.

Hapsari, S. (2005). Bimbingan \& Kons SMA Kls X (2005). Bandung: Grasindo.

Hasan, M. A. (2008). Zakat dan Infak Salah Satu Solusi Mengatasi Problem Sosial di Indonesia. Kencana Prenada Media Group.

Hayati, K., \& Caniago, I. (2011). Zakat Potential As a Means To Overcome Poverty ( a Study in Lampung ), 26(2), 2011.

Inoed, A. (2005). Anatomi Fiqh Zakat. Sumatera: Pustaka Pelajar.

M. Moeliono, A. (1999). Kamus besar bahasa Indonesia. Jakarta: Balai Pustaka. 
Mappiare, A. (2000). Psikologi Remaja. Surabaya: Usaha Offest Printing.

Rangkuti, F. (2009). Strategi Promosi Yang Kreatif \& Analisis Kasus Integrated Marketing Communication. Jakarta: PT Gramedia Pustaka Utama.

Sabiq, S. (1946). Fiqih Sunnah. Depok: Fathan media prima.

Sugiono. (2010). Metode Penelitian Kuantitatif Kualitatif dan $R \& D$. Jakarta: ALFABETA.

Suharyadi, P. S. . (2004). Statistika Untuk Ekonomi \& Keuangan Modern. Jakarta: Salemba Empat.

Wibowo. (2006). Manajemen Perubahan. Jakarta: PT Grasindo Persada. 